\title{
Stability of Oxides Studied with Standard Density Functional Theory
}

\author{
Rossmeisl, Jan; Calle Vallejo, Federico
}

Published in:

Meeting Abstracts - Electrochemical Society

Publication date:

2010

Document Version

Publisher's PDF, also known as Version of record

Link back to DTU Orbit

Citation (APA):

Rossmeisl, J., \& Calle Vallejo, F. (2010). Stability of Oxides Studied with Standard Density Functional Theory. In Meeting Abstracts - Electrochemical Society (pp. Abstract 703). The Electrochemical Society.

\section{General rights}

Copyright and moral rights for the publications made accessible in the public portal are retained by the authors and/or other copyright owners and it is a condition of accessing publications that users recognise and abide by the legal requirements associated with these rights.

- Users may download and print one copy of any publication from the public portal for the purpose of private study or research.

- You may not further distribute the material or use it for any profit-making activity or commercial gain

- You may freely distribute the URL identifying the publication in the public portal

If you believe that this document breaches copyright please contact us providing details, and we will remove access to the work immediately and investigate your claim. 
Stability of oxides studied with standard density functional theory.

Jan Rossmeisl, Federico Calle-Vallejo

Center for Atomic-scale Materials Design, Department of Physics, Technical University of Denmark

Building 311, DTU, 2800 Lyngby

Oxides are in general complicated to treat with standard DFT, especially the formation energy of the oxygen molecule and the electron self-interaction for localized $\mathrm{d}$ and $\mathrm{f}$ electrons are known shortcomings. We present a frame in which it is possible to calculate formation energies of oxides (among those perovskites) based on standard DFT at the GGA level. The idea is to apply a "wet electrochemical reference" " this has the advantages that calculation of the oxygen molecule is avoided and that the oxide Pourbaix diagrams come out as a useful side product. We calculate the change in free energy for a reaction e.g:

$\mathrm{A}(\mathrm{s})+\mathrm{B}(\mathrm{s})+3 \mathrm{H}_{2} \mathrm{O} \rightarrow \mathrm{ABO}_{3}+3 \mathrm{H}_{2}$,

where water is applied as reference energy for of the oxygen atoms. Other references can be used by adding the relevant energy difference accordingly.

The calculated formation energies are compared to experimental literature and the absolute mean error is small (always smaller than $0.3 \mathrm{eV}$ per formula uint). This allows us to systematic calculate energies for mixed oxides with dopends. The results can be used as a search criteria in designing new perovskite materials with better properties.

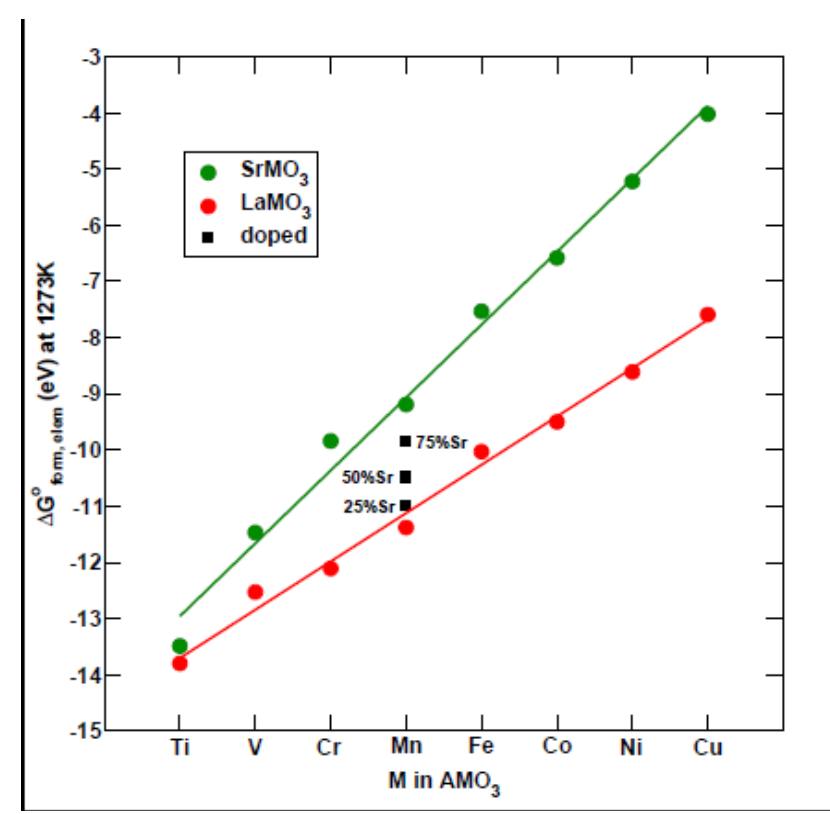

Fig. Calculated formation energies as function of the $\mathrm{B}$ atom position is the periodic table. With the $\mathrm{A}$ atom being either $\mathrm{La}$ or $\mathrm{Sr}$. $\mathrm{La}_{\mathrm{x}} \mathrm{Sr}_{1-\mathrm{x}} \mathrm{MnO}_{3}$ formation energies are shown in black.

\footnotetext{
1 "Formation energies of rutile metal dioxides using density functional theory" J.I Martinez, H.A. Hansen, J.Rossmeisl, J.K. Nørskov, Physical Review B. 79, 045120, (2009)
} 